\title{
Needs analysis of physics e-module based on hybrid-PBL model on critical thinking skills improvement
}

\author{
Fitri Rahmawati ${ }^{\text {* }}$, Sarwanto Sarwanto ${ }^{\mathrm{b}}$, Sri Budiawanti ${ }^{\mathrm{c}}$ \\ Universitas Sebelas Maret. JI. Ir. Sutami No. 36, Kota Surakarta, Jawa Tengah 57126, Indonesia \\ a fitrirachma96@gmail.com; ${ }^{b}$ sarwanto_fkip@staff.uns.ac.id; ${ }^{c}$ awanty77@yahoo.com \\ * Corresponding Author.
}

Received: 2 June 2021; Revised: 23 July 2021; Accepted: 30 July 2021

\begin{abstract}
The purpose of this study was to determine the need for teaching materials in the form of physics e-module based on Hybrid-PBL model in schools. This research applied a descriptive method. Data were collected using a needs analysis questionnaire with 14 respondents of physics teachers spread across several regions in Indonesia and 36 respondents of class XI students in SMA Negeri 2 Sragen. Based on the results of the questionnaire, the teachers indeed need teaching materials in the form of e-module and all teachers also agree that the Hybrid-PBL model can be applied in physics learning. Students are also interested in learning physics using teaching materials that can display images, videos, animations, and simulations as well as learning by involving problems in the surrounding environment. So it can be concluded that teachers and students need a physics e-module based on Hybrid-PBL model.

Keywords: e-module; Hybrid-PBL; Critical thinking
\end{abstract}

How to Cite: Rahmawati, F., Sarwanto, S., \& Budiawanti, S. (2021). Needs analysis of physics emodule based on Hybrid-PBL Model on critical thinking skills improvement. Momentum: Physics Education Journal, 5(2), 175-181. https://doi.org/10.21067/mpej.v5i2.5740

\section{Introduction}

Technological change is a challenge being faced in order to be able to compete in world competition. Have not finished yet with the era of the industrial revolution 4.0, Indonesia is faced with the concept of a new life order, namely society 5.0. This concept aims to create a human-centered society in the technological era and also to overcome some of the negative aspects that come with rapid change (Aprilisa, 2020). Education in Indonesia is currently in the era of the industrial revolution 4.0, or the era of technology-oriented human life (Putri \& Syafriani, 2020). Education requires roles in various fields in order to produce competent graduates. The learning process in high technology-based active classes has superior values than low-technology classes (Nicol et al., 2018). In addition, the use of technology in learning can increase student interest (Andrew et al., 2018).

The key to problem solving in education is the ability to think critically (Sujanem et al., 2018). Critical thinking skill is the intelligence needed by students in the 21st century period (Khoiriyah \& Suprapto, 2021). Critical thinking is a deep reflective thinking skill in making decisions and solving problems to analyze situations, evaluate arguments, and draw conclusions (Rahmawati et al., 2019). Critical thinking allows students to process information logically and prepare them for independent learning and have the ability to determine which information is important, irrelevant, or impractical (Amin et al., 2020). Selection of appropriate teaching materials and learning models can be one solution to create an effective learning process. Teaching materials are a set of learning tools consisting of subject matter, methods, and evaluations that are systematically arranged to achieve the expected competencies (Hendriana et al., 2019). By utilizing current technological advances, modules can be found in electronic form (e-modules) which are specially designed according to 
learning materials and can be used easily by educators (Sofyan et al., 2019). E-Modul or Electronic module is one of the teaching materials that utilize technology to support the learning process. The use of e-modules allows students to learn more flexibly regardless of time and place.

To maximize the use of technology as a teaching material, an appropriate learning model is needed. Problem-based learning (PBL) is a student-centered instructional approach to improve problem solving skills (More et al., 2020). In addition, the problem-based learning (PBL) model is also effective in improving students' critical thinking skills compared to traditional learning (Saputro et al., 2020) and also improves critical thinking skills on physics material (Sulasih et al., 2018).

The problem-based learning (PBL) model has several weaknesses, namely it requires changes in students' mentality and learning behavior and requires teacher readiness to accept failure in students who are accustomed to using traditional learning model or lecture model (Tan \& Shen, 2018). In addition, in the implementation of the problem-based learning (PBL) model, several problems were found, such as low student initiative and inadequate problem design. Therefore, many researchers supported PBL as a complement to the lecture method (Liu et al., 2020). The use of problem-based learning (PBL) model in the learning process takes a long time. This is because students must be active in formulating the problems that have been given, especially schools that rarely use the Problem-based learning model (Salari et al., 2018). Moreover, many institutions in Indonesia believe that it is difficult for teachers and students to transform student-centered learning (Leatemia et al., 2016). To overcome this, the problem-based learning (PBL) model innovates into a hybrid problem-based learning (Hybrid-PBL).

The Hybrid-PBL model is a combination of case discussion or PBL method along with traditional lecture-based method (Kharay et al., 2018). This model is a transition from traditional learning to PBL (Malik \& Malik, 2018). In addition, the Hybrid-PBL model can also improve student learning outcomes, such as long-term knowledge acquisition, problem-solving skills, and generic competencies (Carrió et al., 2016). Thus, this learning model can help transition from a teacher-centered model to a model based on a student-centered approach.

This study aims to determine the need for teaching materials in the form of physics e-module based on Hybrid-PBL on students' critical thinking skills. In this study, an analysis of the needs of teachers and students was carried out as well as product development in accordance with the research results obtained.

\section{Method}

This study is a descriptive study using qualitative data analysis (Doyle et al., 2020). The sample in this study involved 14 high school physics teachers in several regions in Indonesia and 36 class XI students at SMA Negeri 2 Sragen. The sampling technique used was purposive sampling. This technique was chosen because it is widely used in qualitative research to select subjects according to the research objectives (Mayasari, 2020; Palinkas et al., 2015).

Table 1. Percentage Category (Munggaran, 2012)

\begin{tabular}{cc}
\hline Percentage & Category \\
\hline $0-1 \%$ & None \\
$2 \%-25 \%$ & A little \\
$26 \%-49 \%$ & Less than a half \\
$50 \%$ & A half \\
$51 \%-75 \%$ & More than a half \\
$76 \%-99 \%$ & Mainly \\
$100 \%$ & A whole \\
\hline
\end{tabular}

Data collection using an online questionnaire via google forms. Teachers and students were given a questionnaire containing several statements related to the physics learning process, the availability of teaching materials that support physics learning, and students' critical thinking skills. The questionnaire given has a Guttman scale rating type with "yes" and "no" answer options. This scale was chosen because it provides a clear answer so that results are obtained regarding the needs 
of the e-module to be developed. All answers were coded as 1 and 0 (Alvarelhão \& Lopes, 2016). For positive statements, the answer "yes" is scored 1 and the answer "no" is scored 0. As for negative statements, the answer "yes" is cored 0 and the answer "no" is scored 1.

The data analysis technique used is descriptive analysis to describe the research variables (Munggaran, 2012). For statistical techniques, this study uses percentages to be translated into the table categories (Table 1).

\section{Results and Discussion}

Data collection in this study aims to determine the characteristics of e-module requirements that need to be developed. Based on the results of the needs analysis questionnaire, teachers and students stated that e-modules based on the Hybrid-PBL model are needed to improve critical thinking skills. The results of the questionnaire analysis of teacher needs are presented in Table 2.

Table 2. The results of the teacher needs analysis questionnaire about the physics e-module based on HybridPBL (Solihudin, 2018)

\begin{tabular}{|c|c|c|c|}
\hline \multirow[t]{2}{*}{ Measured Aspect } & \multirow[t]{2}{*}{ Indicator } & \multicolumn{2}{|c|}{$\begin{array}{l}\text { Frequency of } \\
\text { response (\%) }\end{array}$} \\
\hline & & Yes & No \\
\hline \multirow[t]{4}{*}{ Learning Process } & $\begin{array}{l}\text { The lecture method makes it easier for students to understand } \\
\text { physics concepts }\end{array}$ & $57,1 \%$ & $41,9 \%$ \\
\hline & $\begin{array}{l}\text { The implementation of the PBL model by relating daily events } \\
\text { in physics learning }\end{array}$ & $85,7 \%$ & $14,3 \%$ \\
\hline & $\begin{array}{l}\text { The teacher has ever implemented the Hybrid-PBL model in } \\
\text { physics learning }\end{array}$ & $57,1 \%$ & $42,9 \%$ \\
\hline & Hybrid-PBL model can be implemented in physics learning & $100 \%$ & $0 \%$ \\
\hline \multirow[t]{2}{*}{$\begin{array}{l}\text { The use of teaching } \\
\text { material }\end{array}$} & $\begin{array}{l}\text { Teachers need teaching materials that support them to learn } \\
\text { physics }\end{array}$ & $92,9 \%$ & $7,1 \%$ \\
\hline & $\begin{array}{l}\text { Teachers need pictures, videos, animations, and simulations in } \\
\text { the physics learning process }\end{array}$ & $100 \%$ & $0 \%$ \\
\hline \multirow[t]{3}{*}{ Critical thinking skills } & Availability of physics e-modules in schools & $35,7 \%$ & $64,3 \%$ \\
\hline & $\begin{array}{l}\text { Physics teaching materials support students' critical thinking } \\
\text { skills }\end{array}$ & $42,9 \%$ & $57,1 \%$ \\
\hline & It is difficult to teach critical thinking skills & $57,1 \%$ & $42,9 \%$ \\
\hline
\end{tabular}

Based on Table 2, it is known that more than half of the teachers agree that the lecture method makes it easier to understand the concept of physics. In fact, learning using the lecture method makes the student learning process passive (Lian \& He, 2013). This is not in accordance with changes in the curriculum in Indonesia which prioritizes an active learning process. Problem-based learning (PBL) is a model that encourages student-centered learning (Lim, 2012). Most teachers have implemented a problem-based learning (PBL) model by relating daily events. This model involves students to learn in real problems (Munawaroh, 2020). About $57.1 \%$ or more than half of teachers have applied the Hybrid-PBL learning model in physics learning. The implementation of the HybridPBL Model is by giving students a problem to be solved in groups, then lecture model is still used to present basic concepts and difficult topics (Kharay et al., 2018). The results of the questionnaire also show that all teachers agree that the Hybrid-PBL model can be implemented in physics learning.

Based on the results of the questionnaire, most of the teachers or $92.9 \%$ needed teaching materials that support the learning of physics. All teachers also need pictures, videos, animations and simulations to support the physics learning process. E-modules are teaching materials that can be a solution in the learning process. The e-module learning design can increase student motivation in learning, involve sensory activities, provide direct feedback, provide opportunities for students to determine the acceleration of their learning, and be able to conduct self-evaluations (Yulando et al., 2019). This is also supported by the questionnaire that more than half of the teachers or $64.3 \%$ do not have e-modules in the schools where they teach. The results of the questionnaire also show that 
teaching materials that support critical thinking skills are only $42.9 \%$ or less than half. Meanwhile, as many as $57.1 \%$ or more than half of the teachers find it difficult to teach something related to students' critical thinking skills. This does not yet reflect the characteristics of the learning process in the era of the industrial revolution 4.0, one of which puts forward critical thinking skills (Hikayat et al., 2020).

The results of student responses to the needs for physics e-module teaching materials based on Hybrid-PBL are presented in Table 3.

Table 3. The results of the student needs analysis questionnaire about the physics e-module based on HybridPBL (Solihudin, 2018)

\begin{tabular}{|c|c|c|c|}
\hline \multirow[t]{2}{*}{ Measured Aspect } & \multirow[t]{2}{*}{ Indicator } & \multicolumn{2}{|c|}{$\begin{array}{c}\text { Response } \\
\text { frequency (\%) }\end{array}$} \\
\hline & & Yes & No \\
\hline Response in physics & Happy and interested in studying physics & $73 \%$ & $27 \%$ \\
\hline learning & Difficult in studying physics & $86,5 \%$ & $13,5 \%$ \\
\hline \multirow{2}{*}{$\begin{array}{l}\text { The use of teaching } \\
\text { materials }\end{array}$} & Have a textbook or other handbook for studying physics & $73 \%$ & $27 \%$ \\
\hline & Have a physics module & $45,9 \%$ & $54,1 \%$ \\
\hline $\begin{array}{l}\text { Use of technology in } \\
\text { teaching materials }\end{array}$ & $\begin{array}{l}\text { Enjoy studying physics by using teaching materials that } \\
\text { contain pictures, videos, animations and simulations }\end{array}$ & $86,5 \%$ & $13,5 \%$ \\
\hline \multirow[t]{2}{*}{ Physics learning process } & Relate with everyday life & $91,9 \%$ & $8,1 \%$ \\
\hline & $\begin{array}{l}\text { Interested in learning physics by involving problems in the } \\
\text { surrounding environment }\end{array}$ & $94,6 \%$ & $5,4 \%$ \\
\hline \multirow[t]{4}{*}{ Critical thinking skills } & Difficult in explaining simple concepts & $54,1 \%$ & $45,9 \%$ \\
\hline & Learn basic skills by observing and considering the results & $86,5 \%$ & $13,5 \%$ \\
\hline & Difficult in defining physics concepts & $62,2 \%$ & $37,8 \%$ \\
\hline & Designing an experiment to prove a physics statement & $35,1 \%$ & $64,9 \%$ \\
\hline
\end{tabular}

Based on Table 3, it is known that more than half or as much as $73 \%$ of students are interested in studying physics. However, most of the students stated that it was difficult to study physics with a percentage reaching $86.5 \%$. From the questionnaire, it was also found that most of the students enjoyed studying physics using teaching materials that contained pictures, videos, animations and simulations. Meanwhile, students' critical thinking skills are classified as low. This is indicated by the results of the questionnaire where almost all indicators have not been met.

The design of the physics e-module to improve critical thinking skills is that students are given problems at the beginning of learning, according to the Hybrid-PBL model. Problems that can be taken are real problems which are commonly found in everyday life. For example, the impact generated by sound waves such as the explosion in Beirut, Lebanon that caused people to experience temporary deafness and damaged buildings. Based on these events, students can perform analysis and problem solving. Through the learning process, students are supported to think critically to solve a problem.

The findings in this study indicate that both teachers and students need physics e-module based on Hybrid-PBL to improve critical thinking skills. This E-Module combines the learning stages of the problem-based learning model with the lecture method. In addition, the e-module that will be developed according to the results of the questionnaire is capable of displaying images, animations and simulations. The use of e-modules is needed by students to make it easier for them in the learning process (Kurniati et al., 2021). In addition, the use of the Hybrid-PBL model in the learning process obtains better results compared to only traditional learning (More et al., 2020). Thus, it is necessary to develop an physics e-module based on Hybrid-PBL.

\section{Conclusion}

Based on the results of research and discussion, the teaching materials in the form of emodules that support the physics learning process are still limited. The lecture method is still a method that is widely implemented in the physics learning process. Students are also interested in 
using learning models related to events in everyday life. In addition, students enjoy learning physics using teaching materials that can display images, videos, animations and simulations. Other findings also show that teaching materials that support critical thinking skills are still limited. This is also supported by the fact that the students' critical thinking skills are still low. Thus, it can be concluded that teachers and students need physics teaching materials in the form of e-modules that are able to display images, animations, videos and simulations and can improve their critical thinking skills. Therefore, the teaching materials in the form of e-module based on the Hybrid-PBL model needs to be developed.

\section{References}

Alvarelhão, J., \& Lopes, D. (2016). A Guttman scale to assess knowledge about sexually transmitted diseases in adults with cerebral palsy. Sexuality and Disability, 34(4), 485-493. https://doi.org/10.1007/s11195-016-9454-8

Amin, A. M., Corebima, A. D., Zubaidah, S., \& Mahanal, S. (2020). The correlation between metacognitive skills and critical thinking skills at the implementation of four different learning strategies in animal physiology lectures. European Journal of Educational Research, 9(1), 143163. https://doi.org/10.12973/eu-jer.9.1.143

Andrew, M., Taylorson, J., Langille, D. J., Grange, A., \& Williams, N. (2018). Student attitudes towards technology and their preferences for learning tools/devices at two universities in the UAE. Journal of Information Technology Education: Research, 17, 309-344. https://doi.org/10.28945/4111

Aprilisa, E. (2020). Realizing society 5.0 to face the industrial revolution 4.0 and teacher education curriculum readiness in Indonesia. Proceeding International Conference on Science and Engineering, 3, 543-548. https://doi.org/10.14421/icse.v3.559

Carrió, M., Agell, L., Banõs, J. E., Moyano, E., Larramona, P., \& Pérez, J. (2016). Benefits of using a hybrid problem-based learning curriculum to improve long-term learning acquisition in undergraduate biology education. FEMS Microbiology Letters, 363(15), 1-22. https://doi.org/10.1093/femsle/fnw159

Doyle, L., McCabe, C., Keogh, B., Brady, A., \& McCann, M. (2020). An overview of the qualitative descriptive design within nursing research. Journal of Research in Nursing, 25(5), 1-13. https://doi.org/10.1177/1744987119880234

Hendriana, H., Putra, H. D., \& Hidayat, W. (2019). How to design teaching materials to improve the ability of mathematical reflective thinking of senior high school students in Indonesia? Eurasia Journal of Mathematics, Science and Technology Education, 15(12), 1-20. https://doi.org/10.29333/ejmste/112033

Hikayat, C., Suparman, Hairun, Y., \& Suharna, H. (2020). Design of realistic mathematics education approach to improve critical thinking skills. Universal Journal of Educational Research, 8(6), 2232-2244. https://doi.org/10.13189/ujer.2020.080606

Kharay, S. S., Sharma, A., \& Bansal, P. (2018). Evaluation of hybrid problem-based learning in large classrooms: a qualitative and quantitative analysis. International Journal of Research in Medical Sciences, 6(11), 3623-3628. https://doi.org/10.18203/2320-6012.ijrms20184419

Khoiriyah, S., \& Suprapto, N. (2021). Effectiveness of comics to train students' critical thinking skills in physics learning: A mini-review. Studies in Learning and Teaching, 2(1), 5-15.

https://doi.org/10.46627/silet.vi.49

Kurniati, R. D., Andra, D., \& Wayan Distrik, I. (2021). E-module development based on PBL integrated STEM assisted by social media to improve critical thinking skill: A preliminary study. IOP Conference Series: Earth and Environmental Science, 1796(1), 1-10. https://doi.org/10.1088/1742-6596/1796/1/012077

Leatemia, L. D., Susilo, A. P., \& van Berkel, H. (2016). Self-directed learning readiness of Asian 
students: students perspective on a hybrid problem based learning curriculum. International Journal of Medical Education, 7, 385-392. https://doi.org/10.5116/ijme.582e.021b

Lian, J., \& He, F. (2013). Improved performance of students instructed in a hybrid PBL format. Biochemistry and Molecular Biology Education, 41(1), 5-10. https://doi.org/10.1002/bmb.20666

Lim, W. K. (2012). Dysfunctional problem-based learning curricula: resolving the problem. BMC Medical Education, 12(1), 89. https://doi.org/10.1186/1472-6920-12-89

Liu, C., Ouyang, W., Wang, X., Chen, D., \& Jiang, Z. (2020). Comparing hybrid problem-based and lecture learning $(P B L+L B L)$ with $L B L$ pedagogy on clinical curriculum learning for medical students in China: a meta-analysis of randomized controlled trials. Medicine, 99(16), e19687. https://doi.org/10.1097/MD.0000000000019687

Malik, A. S., \& Malik, R. H. (2018). What really is hybrid problem-based learning curriculum? A review. Quest International Journal of Medical and Health Sciences, 1(227), 8-18. https://ojs.qiu.edu.my/journal/index.php/qijmhs/article/view/7

Mayasari, D. (2020). Konstruksi tuturan masyarakat Manduro sebagai pendukung pembelajaran bahasa Indonesia. Journal of Applied Linguistics, Translation, and Literature, 1(2), 41-53. https://doi.org/10.33292/jalintrali.v1i2.42

More, V. R., Singh, G., \& Patwardhan, K. (2020). Introducing hybrid problem-based learning modules in Ayurveda education: Results of an exploratory study. The Journal of Alternative and Complementary Medicine, 26(2), 130-137. https://doi.org/10.1089/acm.2019.0293

Munawaroh. (2020). The influence of problem-based learning model as learning method, and learning motivation on entrepreneurial attitude. International Journal of Instruction, 13(2), 431444. https://doi.org/10.29333/iji.2020.13230a

Munggaran, R. (2012). Pemanfaatan open source software pendidikanoleh mahasiswa dalam rangka implementasi Undang-Undang No. 19 Tahun 2002 tentang hak cipta intellectual property rights [Universitas Pendidikan Indonesia]. http://repository.upi.edu/9024/

Nicol, A. A. M., Owens, S. M., Le Coze, S. S. C. L., Maclntyre, A., \& Eastwood, C. (2018). Comparison of high-technology active learning and low-technology active learning classrooms. Active Learning in Higher Education, 19(3), 253-265. https://doi.org/10.1177/1469787417731176

Palinkas, L. A., Horwitz, S. M., Green, C. A., Wisdom, J. P., Duan, N., \& Hoagwood, K. (2015). Purposeful sampling for qualitative data collection and analysis in mixed method implementation research. Administration and Policy in Mental Health and Mental Health Services Research, 42(5), 533-544. https://doi.org/10.1007/s10488-013-0528-y

Putri, S. R., \& Syafriani, S. (2020). Analysis development of guided inquiry based physics e-module to improve critical thinking ability of students high school. Journal of Physics: Conference Series, 1481(1), 1-7. https://doi.org/10.1088/1742-6596/1481/1/012063

Rahmawati, L., Subanji, \& Septi Nur Afifah, D. (2019). Analysis of critical thinking from student with quantive approach. Journal of Physics: Conference Series, 1339(1), 012084. https://doi.org/10.1088/1742-6596/1339/1/012084

Salari, M., Roozbehi, A., Zarifi, A., \& Tarmizi, R. A. (2018). Pure PBL, Hybrid PBL and Lecturing: Which one is more effective in developing cognitive skills of undergraduate students in pediatric nursing course? BMC Medical Education, 18(1), 1-15. https://doi.org/10.1186/s12909-0181305-0

Saputro, A. D., Atun, S., Wilujeng, I., Ariyanto, A., \& Arifin, S. (2020). Enhancing pre-service elementary teachers' self-efficacy and critical thinking using problem-based learning. European Journal of Educational Research, 9(2), 765-773. https://doi.org/10.12973/eu-jer.9.2.765

Sofyan, H., Anggraeni, E., \& Saadiah, J. (2019). Development of e-modules based on local wisdom in central learning model at kindergartens in Jambi City. European Journal of Educational 
Research, 8(4), 1137-1143. https://doi.org/10.12973/eu-jer.8.4.1137

Solihudin JH, T. (2018). Pengembangan e-modul berbasis web untuk meningkatkan pencapaian kompetensi pengetahuan fisika pada materi listrik statis dan dinamis SMA. WaPFi (Wahana Pendidikan Fisika), 3(2), 51. https://doi.org/10.17509/wapfi.v3i2.13731

Sujanem, R., Poedjiastuti, S., \& Jatmiko, B. (2018). The Effectiveness of problem-based hybrid learning model in physics teaching to enhance critical thinking of the students of SMAN. Journal of Physics: Conference Series, 1040(1), 1-7. https://doi.org/10.1088/1742-6596/1040/1/012040

Sulasih, S., Sarwanto, S., \& Suparmi, S. (2018). Physics Learning with Metacognitive Approach through Problem Based Learning (PBL) and Reciprocal Learning (RL) model Viewed from Students' Critical Thinking Skill. International Journal of Pedagogy and Teacher Education, 2, 69-77. https://doi.org/10.20961/ijpte.v2i0.19896

Tan, S., \& Shen, Z. (2018). Hybrid problem-based learning in digital image processing: A case study. IEEE Transactions on Education, 61(2), 127-135. https://doi.org/10.1109/TE.2017.2766155

Yulando, S., Sutopo, S., \& Franklin Chi, T. (2019). Electronic module design and development: An interactive learning. American Journal of Educational Research, 7(10), 694-698.

https://doi.org/10.12691/education-7-10-4 